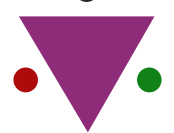

IJCRR

Section: Healthcare

Sci. Journal Impact

Factor: $6.1(2018)$

ICV: 90.90 (2018)

(c) (7) (8)

Copyright@IJCRR

\title{
Prevalence of Cancer Among Different Subsites in the Oral Cavity
}

\section{Vivek D. Menon' ${ }^{1}$, M R Muthusekhar², Dinesh Prabu ${ }^{3}$}

'Saveetha Dental College and Hospitals, Saveetha Institute of Medical and Technical Sciences, Saveetha University, Chennai, India; ${ }^{2}$ Professor and Head of Department, Saveetha Dental College and Hospitals, Saveetha Institute of Medical and Technical Sciences, Saveetha University, Chennai, India; ${ }^{3}$ Senior Lecturer, Saveetha Dental College and Hospitals, Saveetha Institute of Medical and Technical Sciences, Saveetha University, Chennai, India.

\section{ABSTRACT}

Aim: To assess the prevalence of different sites of oral cancer.

Materials and Methods: A retrospective study was done in an institutional setting. The data for the study was retrieved from the college's patient records. All the patients who underwent management of oral cancer at a given time frame from June 2019 - March 2020 were taken into consideration. The patient's name, age, gender, and site of lesion were retrieved and tabulated. The data was analyzed using software (SPSS).

Results: A total 41 patients were included in this study, 33 being males and 8 female patients. The common site of occurrence of cancer was found to be most in buccal vestibule (39\%), tongue $(26.8 \%)$, buccal mucosa $(12.2 \%)$, retromolar area $(12.2 \%)$, alveolar mucosa $(2.4 \%)$, lip $(2.4 \%)$, neck $(2.4 \%)$, and chest $(2.4 \%)$. The majority of the patients who participated in this study were between 41-50 years of age. A cross analysis between age and site of cancer and gender and site of cancer was done. The most common age was found to be 41-50 years and more cases were seen in male patients.

Conclusion: The most common site of cancer was found to be in buccal vestibule. More number of cases was seen in male patients and the age group in which most cases were seen was 41-50 years.

Key Words: Oncology, Occurrence, Site, Head and neck, Carcinoma

\section{INTRODUCTION}

Oral cancers are malignant lesions occurring in the oral cavity that include squamous cell carcinomas (SCC), salivary gland and odontogenic neoplasms commonly. The majority (84-97\%) of oral cancers are squamous cell carcinoma and they arise from pre-existing "potentially malignant" lesions or more often from normal appearing epithelium. ${ }^{1,2}$ Oral cancer spreads locally involving perioral structures and metastasises to local regional lymph nodes. The burden caused by Oral cancer is great because of the associated high cost of treatment, permanent impairment and high mortality. ${ }^{3,4}$ Asians have various cultural practices such as betel-quid chewing as well as different forms of use of tobacco and alcohol which are important risk factors that predispose to cancer of oral cavity. In Asian countries many changes are being observed in several factors including site of occurrence, male to female ratio, age and occurrence in people with no known risk habits. Oral cancer is a major public health prob- lem in India, where it ranks among the top three types of cancer in the country. ${ }^{5,6}$ The low-income groups in India are affected most due to a variety of exposure to risk factors such as tobacco chewing, betel nut and insufficient exposure to new diagnostic aids, resulting in a delayed reporting of oral cancer. ${ }^{7,89}$ This study will give us an idea about the various sites of occurrence and the gender predilection in general.

\section{MATERIALS AND METHODS}

A retrospective study was conducted in an institutional setting. The ethical clearance was received from the institutional ethical committee. The study involved all the patients who had undergone management of cancer in a given time frame. The time period of choice was from June 2019 to March 2020. There were three people involved in this study are guide, reviewer, and researcher. All available data was collected and tabulated. The patient's details were retrieved

\section{Corresponding Author:}

Dr. M R Muthusekhar, Professor and Head of Department, Saveetha Dental College and Hospitals, Saveetha Institute of Medical and Technical Sciences, Saveetha University, Chennai, India; Email: muthusekar@saveetha.com

ISSN: 2231-2196 (Print)

Received: 20.09 .2020
ISSN: 0975-5241 (Online)

Revised: 15.10 .2020
Accepted: 18.11 .2020
Published: 26.12 .2020 
from the institute's patient records. A total of 86000 cases were reviewed and analyzed. Data regarding patients age, gender, and site of cancer were considered for this study. Cross verification of the data was done by the second reviewer, to avoid any missing or repetitive data. The data was manually retrieved and tabulated in excel sheet and sorted.

Inclusion Criteria: All patients who underwent management of cancer were included in this study. All age groups were considered.

Exclusion Criteria: Patients with incomplete records were removed from the study. Repetitive entries were also excluded.

The tabulated data was analysed using SPSS software (im SPSS statistics 260). The method of analysis that was used was "Chi square test". The analysis was done between age and site of occurrence, gender, and site of occurrence.

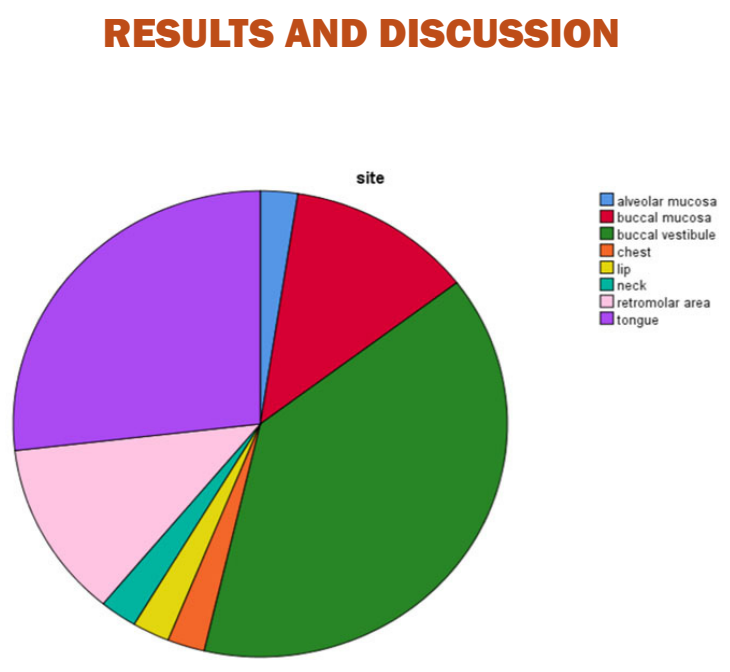

Figure 1: This pie chart depicts the percentage distribution in different sites of cancer.
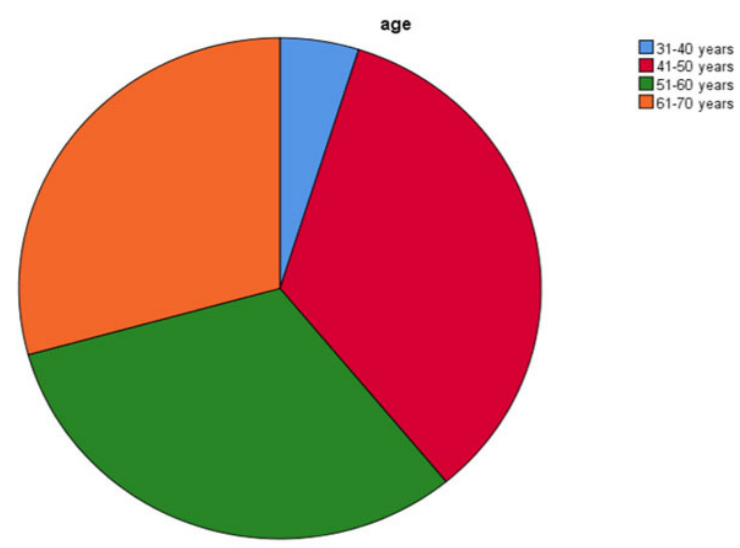

Figure 2: This pie chart depicts the age distribution of cancer.

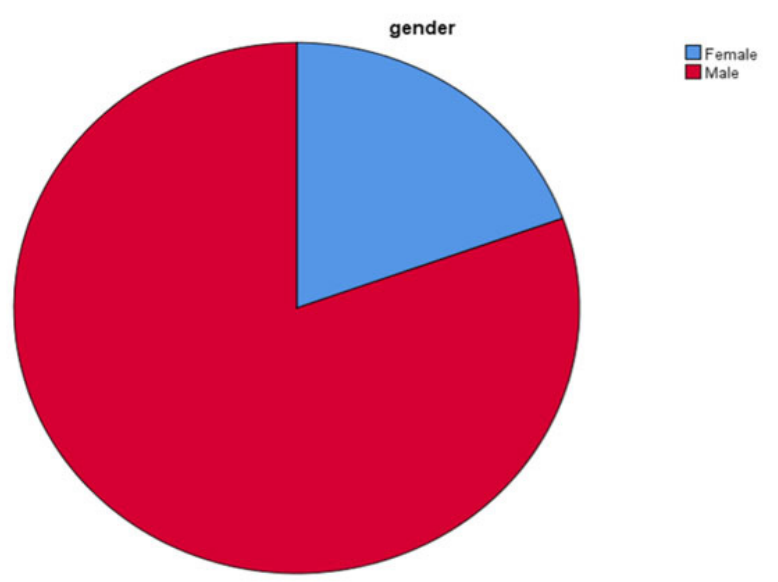

Figure 3: This pie chart depicts the gender distribution of cancer

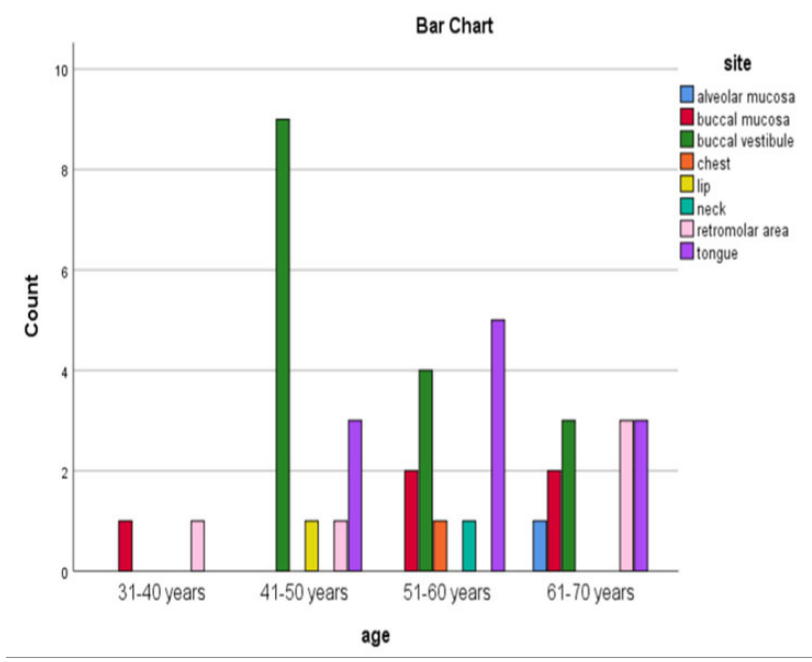

Figure 4: This graph depicts the association between site of cancer and age. $X$ axis: age groups of patients, $Y$ axis: site of cancer. $P$ value is 0.288 , statistically insignificant.

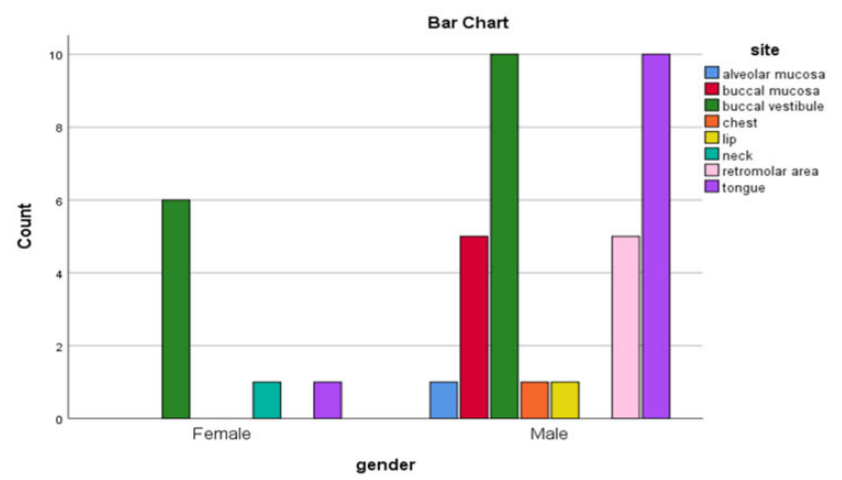

Figure 5: This graph depicts the association between cancer and gender. $X$ axis: gender, $Y$ axis: site of cancer. $P$ value is 0.125 , statistically insignificant. 
The present clinical study was done to determine the most common site of occurrence of cancer

Among the 41 patients who were included in this study, the site of cancer was most commonly seen in the buccal vestibule region $(39 \%)$, followed by tongue $(26.8 \%)$, buccal mucosa $(12.2 \%)$, retromolar area $(12.2 \%)$, alveolar mucosa $(2.4 \%)$, lip (2.4\%), neck (2.4\%), and chest $(2.4 \%)$. Oral cancer showed more predilection for the age group 41-50 years, followed by 51-60 years, 61-70 years (29.3\%), and then 31 40 years $(4.9 \%)$, an increased number of cases were seen in male patients than female patients which is supported by. ${ }^{10,11}$ According to ${ }^{10,12,13}$, the most common site of occurrence of cancer was found to be tongue follwed by buccal mucosa. In our study it was found that buccal vestibule was the most common site followed by tongue and buccal mucosa. The site of occurrence depends mainly on the predominant risk factors in that particular geographical region. Cheek or buccal mucosa cancers exceed all other oral cancers in other places like Pakistan, Uttar Pradesh state in India and Changua County in Taiwan. ${ }^{14,15,16}$

In recent years many countries report the tongue as the most frequently affected site. In Japan, Taiwan, Thailand, Yemen, India and Iran, the tongue is the foremost among all sites contributing up to $42 \%$ of all oral sites in adults of all ages. ${ }^{17,18}$ Oral cancer is considered to be a disease that occurs mainly in the elderly. However, while most of the cases of OC occur between 50 and 70 years of age (Bhurgri et al., 2006) ${ }^{19}$, it still could occur in children as early as 10 years of age in the absence of any known risk factors. ${ }^{20,21}$ The mean age of occurrence of cancer in different parts of oral cavity is usually between 51-55 years in most of the countries but higher around 64 years, in Thailand ${ }^{22,23}$ In our study it was found that the mean age occurrence of oral cancer was between 51-60 years, which is in accordance to the above mentioned study. Oral cavity cancers were traditionally being thought of as a disease mainly affecting people of older age group mainly. The increased incidence of oral cancer at a younger age group has been usually attributed to increased usage of substances, mainly tobacco and tobacco-related products, over a prolonged period of time, which leads to genetic damage. Considering gender, men are more affected than women. This is true when we observe male to female ratio which is 1.45 in Japan. ${ }^{24,25}$ The above study we observe only a slight increase in number of male patients than female patients. A few reports from one of the Indian registries and Pakistan show equal male to female ratio of $1 .{ }^{26,27}$

\section{CONCLUSION}

This study gives us an overview about the various sites of cancer and also the frequency of distribution among age groups and gender. There are dissimilarities in the incidence rates of oral cancer across different countries in Asia. While there are some common habits like use of tobacco, alcohol and quid chewing there are some differences in the prevalence of habits, in addition to some still unknown or unexplained factors other than social and economic factors in these Asian countries. It is necessary to improve the living standards of people and health care systems where access to health care is poor or limited.

\section{Acknowledgement: Nil}

Funding: Nil

\section{REFERENCES}

1. Bhurgri Y. Karachi Cancer Registry Data--implications for the National Cancer Control Program of Pakistan. Asian Pac J Cancer Prev 2004;5(1):77-82.

2. Mp SK, Rahman R. Knowledge, Awareness, And Practices Regarding Biomedical Waste Management Among Undergraduate Dental Students. Asian J Pharm and Clini Res 2017;341-5.

3. Reichart PA, Way TH. Oral cancer and pre-cancer in Myanmar: a short review. J Oral Pathol and Med 2006;35:193-6.

4. Jesudasan JS, Wahab PUA, Sekhar MRM. Effectiveness of $0.2 \%$ chlorhexidine gel and a eugenol-based paste on postoperative alveolar osteitis in patients having third molars extracted: a randomised controlled clinical trial. Br J Oral Maxillofac Surg 2015;53(9):826-30.

5. Sankaranarayanan R, Ramadas K, Thomas G, Muwonge R, Thara S, Mathew B, et al. Effect of screening on oral cancer mortality in Kerala, India: a cluster-randomised controlled trial. Lancet 2005;365:1927-33.

6. Christabel A, Anantanarayanan P, Subash P, Soh CL, Ramanathan M, Muthusekhar MR, et al. Comparison of pterygomaxillary dysjunction with tuberosity separation in isolated Le Fort I osteotomies: a prospective, multi-centre, triple-blind, randomized controlled trial. Int J Oral and Maxillofac Surg 2016;45:180-5.

7. Kumar S, Heller RF, Pandey U, Tewari V, Bala N, Oanh KT. Delay in presentation of oral cancer: a multifactor analytical study. Natl Med J India 2001;14(1):13-7.

8. Marimuthu M, Andiappan M, Wahab A, Muthusekhar MR, Balakrishnan A, Shanmugam S. Canonical Wnt pathway gene expression and their clinical correlation in oral squamous cell carcinoma. Indian J Dent Res 2018;29(3):291-7.

9. Packiri S, Gurunathan D, Selvarasu K. Management of Paediatric Oral Ranula: A Systematic Review. J Clin Diagn Res 2017;11(9):ZE06-9.

10. Rao SVK, Mejia G, Roberts-Thomson K, Logan R. Epidemiology of Oral Cancer in Asia in the Past Decade- An Update (2000-2012). Asian Pac J Cancer Prev 2013;14:5567-77.

11. Santhoshkumar M. Relationship Between Dental Anxiety and Pain Experience During Dental Extractions. Int J Oral Maxillofac Surg 2013;43:994-7.

12. Patil SB, Durairaj D, Suresh Kumar G, Karthikeyan D, Pradeep D. Comparison of Extended Nasolabial Flap Versus Buccal Fat Pad Graft in the Surgical Management of Oral Submucous Fibrosis: A Prospective Pilot Study. J Maxillofac Oral Surg 2017;16(3):312-21.

13. Rao TD, M.P. Santhoshkumar M.D.S. Analgesic Efficacy of Paracetamol Vs Ketorolac after Dental Extractions. Res J Pharm Tech 2018;11(8):3375-9. 
14. Su C-C, Yang H-F, Huang S-J, Lian I-B. Distinctive Features of Oral Cancer in Changhua County: High Incidence, Buccal Mucosa Preponderance, and a Close Relation to Betel Quid Chewing Habit. J Formosan Med Assoc 2007;106:225-33.

15. Sharma P, Saxena S, Aggarwal P. Trends in the epidemiology of oral squamous cell carcinoma in Western UP: an institutional study. Indian J Dent Res 2010;21(3):316-9.

16. Abhinav RP, Selvarasu K, Maheswari GU, Taltia AA. The Patterns and Etiology of Maxillofacial Trauma in South India. Ann Maxillofac Surg 2019;9(1):114-7.

17. Dhar PK, Rao TR, Sreekumaran Nair N, Mohan S, Chandra S, Bhat KR, et al. Identification of risk factors for specific subsites within the oral and oropharyngeal region--a study of 647 cancer patients. Indian J Cancer 2000;37(2-3):114-22.

18. Mp SK, Sneha S. Knowledge and Awareness Regarding Antibiotic Prophylaxis for Infective Endocarditis Among Undergraduate Dental Students. Asian J Pharm and Clini Res 2016;154-9.

19. Kumar S. The Emerging Role Of Botulinum Toxin In The Treatment Of Orofacial Disorders: Literature Update. Asian J Pharm and Clini Res 2017;10:21.

20. Ribeiro CMB, Gueiros LAM, Leon JE, do Carmo Abreu e Lima $\mathrm{M}$, de Almeida OP, Leão JC. Oral squamous cell carcinoma in a 7-year-old Brazilian boy. Int J Oral and Maxillofac Surg 2011;40:994-7.

21. Rahman R, Santhoshkumar M. Knowledge, Attitude, and Awareness of Dental Undergraduate Students Regarding Human Im- munodeficiency Virus/Acquired Immunodeficiency Syndrome Patients. Res J Pharm Tech 2016;9:1349.

22. Bhurgri Y, Bhurgri A, Usman A, Pervez S, Kayani N, Bashir I, et al. Epidemiological review of head and neck cancers in Karachi. Asian Pac J Cancer Prev 2006;7(2):195-200.

23. Sweta VR, Abhinav RP, Ramesh A. Role of Virtual Reality in Pain Perception of Patients Following the Administration of Local Anesthesia. Ann Maxillofac Surg 2019;9(1):110-3.

24. Ariyoshi Y, Shimahara M, Omura K, Yamamoto E, Mizuki H, Chiba H, et al. Epidemiological study of malignant tumors in the oral and maxillofacial region: survey of member institutions of the Japanese Society of Oral and Maxillofacial Surgeons, 2002. Int J Clin Oncol 2008;13(3):220-8.

25. Patturaja K, Pradeep D. Awareness of Basic Dental Procedure among General Population. Res J Pharm and Tech 2016;9:1349.

26. Franceschi S, Bidoli E, Herrero R, Muñoz N. Comparison of cancers of the oral cavity and pharynx worldwide: etiological clues. Oral Oncol 2000;36(1):106-15.

27. Vijayakumar Jain S, Muthusekhar MR, Baig MF, Senthilnathan P, Loganathan S, Abdul Wahab PU, et al. Evaluation of Three-Dimensional Changes in Pharyngeal Airway Following Isolated Lefort One Osteotomy for the Correction of Vertical Maxillary Excess: A Prospective Study. J Maxillofac Oral Surg 2019;18(1):139-46. 